\title{
IMPEDIMENTS TO THE STRUCTURAL DEVELOPMENT OF SOUTH AFRICAN MARITIME SUPPLY CHAINS
}

\author{
YOLANDA FOURIE \\ Department of Transport and Logistics Management \\ University of Johannesburg
}

\begin{abstract}
The progress of the South African economy relies heavily on earnings from physical exports, which depend increasingly on the competitiveness in global markets of the maritime supply chains that serve the country. World best practice requires that those chains should function as entities structured to serve their logistical purpose, while the development of such structured chains requires chain leadership.

Transnet fulfils a prominent role in South Africa's maritime supply chains, but that role, in accordance with the declared policy of the Government, constitutes an impediment to restructuring the chains as competing entities under private leadership. The solution may be found in leadership by public-private partnerships.
\end{abstract}

\section{BACKGROUND}

A consequence of the liberalisation of world trade and the global sourcing of production factors and consumer products is the increasing reliance by manufacturers and traders on international chains of supply. The efficiency of those supply chains has now become of critical importance for successful competition by trading countries in the world markets that have emerged through the dismantling of trade protection. Trade liberalisation has also intensified competition in the markets for services, including international transport services and especially marine transport. That has necessitated the endeavour by the suppliers of line shipping to establish international supply chains in which control is exercised over the multi-modal movement of freight between the origin and destination of the consignments, in order to attract custom by ensuring the success of the products carried in penetrating world markets.

The efforts by liner shipping companies to extend their supply chain operations have involved mainly the backward and forward integration of land transport and intermodal trans-shipment with the marine transport that they supply ${ }^{1}$. International competition for raw materials has also necessitated forward integration by the producers of the products to include rail transport, port loading appliances and sometimes also bulk shipping. The outcome of such link integration in global markets is competition between supply chains rather than between products.

1 For example, the coal line operated by Spoornet in conjunction with Richards Bay Coal Terminal at the port of Richards Bay (Fourie, 2002: 63-66). 


\section{PURPOSE OF ARTICLE}

This article relies on the findings of a research study (Fourie, 2005) concerning the structuring of South Africa's maritime supply chains and is intended to explain the essence of the arguments. The main objectives of the research were to identify weaknesses in the structures of those supply chains and to reach conclusions on the structuring needed to raise their efficiency and to identify impediments that may preclude such restructuring.

As the most important feature of South Africa's maritime supply chains is the stakeholding by the Government in their links through the role of Transnet, the constraint imposed through that role on the development of efficient maritime supply chains in accordance with world best practice is given specific attention. The contention is that the exigencies of competition require international supply chains of goods to function as business entities under a single management, which ensures that the modal and nodal links in the chain are integrated to serve the common purpose of achieving efficient throughput (i.e. at the least overall net cost). As public and private enterprises in South Africa have different business criteria, their inclusion as link operators in a supply chain precludes the achievement of that common purpose, requiring instead a public-private partnership led by a private undertaking to operate and develop the entire chain. In the absence of such an undertaking, maritime supply chains with links operated according to the different purposes of public and private enterprises cannot function with a common business logic.

\section{GOVERNMENT STAKEHOLDING IN SOUTH AFRICAN MARITIME SUPPLY CHAINS}

\section{Role of Transnet}

In terms of the Legal Succession to the South African Transport Services Act 1989 (Act 9 of 1989) and the legislation that it incorporates by succession, South African ports and railways are owned and operated by Transnet Ltd (Transnet), in which the equity belongs entirely to the State. In consequence, Transnet functions as a state enterprise in which the Minister of Public Enterprises on behalf of the Government, as the shareholder, intervenes in important decision-making. Transnet is the sole supplier of port and rail services in South Africa, and is consequently a major stakeholder in many of the country's maritime supply chains.

Most of the bulk exports through South African ports are loaded at private terminals, which constitute links integrated to some extent into supply chains (Merit, 2000), but almost all the public terminals at which imports and exports in containers are handled are operated by Transnet. Therefore the movement of cargo usually involves three separately-managed links in maritime supply chains, i.e. the marine link, trans-shipment at the ports, and inland 
transport provided by private road hauliers or Spoornet (the railway division of Transnet). Slowness in the trans-shipment of cargo in ports is a particular cause of delays, while the lack of investment in rail capacity hampers export of bulk commodities.

\section{Government policy}

The policy of the Government concerning the role of Transnet has been explained by the Minister of Public Enterprises in Parliament (Erwin, 2004). Transnet will remain a state-owned enterprise located within a system of public-private partnerships, "the purpose of which is to achieve higher levels of investment; overall system efficiency for the economy; improved technological capacity; improved management (within public and private entities) of public assets; enhanced human resource capacity; sustainable non-resource financing options and better customer service". Within those partnerships, Transnet will "play the pivotal and decisive role". The Minister also declared that a state-owned enterprise "cannot operate in order to maximise profit; it has to maximise certain economic benefits (or externalities)" and that it "operates in the market but within rules that are not derived from the logic of the market place alone".

The economic policy of the Government concerning state-owned enterprises spells out the conditions under which private developers could incorporate rail and port links in the integration of maritime supply chains in South Africa. However, according to micro-economic logic the leadership of supply chains constructed to export large quantities of mineral and ores should vest in mine owners and that of container supply chains in liner shipping companies. The structural integration of the links of maritime supply chains in order to improve their competitive efficiency in world markets, might consequently be frustrated if Transnet insists on fulfilling the "pivotal and decisive role" in the provision of the rail and port links. Transnet's role in supply chains is seen by the Government as that of a third party service provider independently responsible for decisions concerning investment in links in the chain and the productivity of those links, which precludes the prospect of integrating maritime supply chains to compete in world markets as cost entities. Integrated management might be achievable through the granting of concessions to operate rail links and port terminals, but whether the unit costs of chains so constructed could be reduced to the unit costs of fully-integrated chains is doubtful, especially if Transnet seeks to maintain revenue neutrality when awarding concessions.

Although the declared policy of the Government seems to accord with the outcome of the restructuring of the assets of railways and ports in other countries, with the exception that the assets will not be sold, there are fundamental differences that should not be overlooked. The Government will not allow the private sector to appropriate value for itself by "cherry picking" the most profitable opportunities in order to maximise the rate of return, avoid 
external costs and shorten payback periods (Erwin, 2004). Joint ventures or public-private partnerships with Transnet will be regulated through a complex "contract between two different financing and operational systems - public and private" (Erwin, 2004). Taken together with the constraint that "the (state-owned) enterprise cannot operate in order to maximise profit", it is evident that the policy of the Government will not permit Transnet to participate in schemes in which rail and port links are financially integrated into maritime supply chains in order to achieve their maximum cost efficiency. The Government's policy in the tension between the public and private sectors that "inexorably impels the latter towards appropriating value for itself" (Erwin, 2004) is thus to intervene in what is really the manifestation of the free market by "increasing the public sector in strategic areas through for example, nationalisation, purchasing a shareholding in companies, establishing new corporations or joint ventures with the private sector" (South Africa, 1994, Reconstruction and Development Programme).

\section{SOUTH AFRICAN MARITIME SUPPLY CHAINS}

The major South African maritime supply chains are the chains for the export of iron ore and coal in bulk. There are also several container supply chains for the import of motor vehicle components "just-in-time" and the fruit supply chains which provide for the export of fruit on pallets using chartered refrigerated ships as well as in containers carried by liner shipping.

\section{Bulk supply chains}

The export of iron ore mined in the Northern Cape and transported via the 863 kilometre OREX railway through the Port of Saldanha comprises the South African leg of a supply chain that then fans out to feed some 35 major steel producers in 16 countries, including China, Japan, South Korea, the United Kingdom, Germany, Australia and Italy (Kumba Resources, 2002). Some 29 million tonnes are exported annually and plans exist to raise this to 41 million tonnes.

The "coal line"2 starts in Mpumulanga where 44 coal mines feed the railway, which stretches a distance of 580 kilometres through KwaZulu-Natal to the port of Richards Bay (Spoornet, 2005). Some 68 million tonnes are exported annually and developments are in progress to raise this volume to 82 million tonnes.

\section{Container supply chains}

Examples of container supply chains are those of the motor vehicle manufacturers located inland at Rosslyn near Pretoria through which knocked-down vehicles and components in

2 As described by Transnet in official literature 
containers are imported through the ports of Port Elizabeth and Cape Town, respectively, and fully built-up vehicles are exported through the port of Durban.

\section{SUPPLY CHAINS OVERSEAS}

\section{Container supply chains}

The main container supply chain overseas described in comparison with the local container supply chains is the European Rail Shuttle (ERS), which comprises scheduled shuttle trains with fixed capacities offering direct services at all times on some 62 routes throughout Europe. A feature of ERS is that it is under single management and is also a rail traction provider with its own fleet of locomotives (European Rail Shuttle, 2005).

\section{Bulk supply chains}

The main example of a comparative bulk supply chain is Pilbara Iron in Western Australia, which handles the export of approximately 130 million tonnes of iron ore annually through a network involving nine mines, three ports and the largest privately-owned railway in the world. It was established as an integrated operation in order to ensure effective competition in the global market for iron ore through rapid responsiveness to demand, scheduling flexibility and reliability (Hamersley Iron, 2005).

The significance of the description of Pilbara Iron is that the size of its operations is huge by any measure and that the efficiency of its supply chain organisation has contributed to Australia's predominance in the supply of iron ore to Asian markets.

Undoubtedly, the main competitive advantage of Australian iron ore bulk supply chains stems from the integrated ownership of the links. Thus overall responsibility of the entire operation from the rock face to the ship by a single owner enables the responsiveness to the demand and flexibility of supply essential to market success. Furthermore, integrated ownership enables the supply along the chains to be synchronised with the shipping of the cargo. According to the Minerals Council of Australia (April 2005: 29), "These efficiencies are a major source of competitive advantage for Australia's globally traded iron ore. In fact, this integration has become so advanced that the facilities operate as a unified production process altogether responsive to changes in market demand. Pilbara producers have been able to raise capacity through investments in infrastructure in a way that no other industry can match". 


\section{STRUCTURAL IMPROVEMENT OF SOUTH AFRICA'S MARITIME SUPPLY CHAINS}

\section{Theoretical considerations}

An integrated intermodal supply chain is defined as an intermodal supply chain managed as an entity (Langley, 1995: 21). The term "managed as an entity" with reference to supply chain integration, means managed for the purpose of the whole chain. As that purpose, according to all definitions of supply chains, is to deliver the product to the market at the lowest cost, integration implies the elimination of the management of individual links for profit and by implication the amalgamation of their cost structures. The assets of the links might be owned or leased as long as rentals are market-related. An integrated supply chain is accordingly a chain that no longer constitutes a sequence of profit-seeking links each striving to maximise the value of their assets, but rather a process that maximises the time and place utility of the product it carries. The profitable operation of a supply chain as an entity does not deviate from the principle involved, rather from its application. In a free market, there is often no alternative to operation for that purpose if the disparity between the capacity of the chain and the size of consignments for individual cargo-owners is large.

No recognised theory of supply chain management exists, which is evident from the diversity of concepts, definitions and descriptions found in scientific literature. Lai, Ngai \& Cheng (2001) find it necessary for their purpose to adopt the definition of Christopher (1998), which in effect assumes the aim of supply chain management to be that of delivering superior customer value at less cost to the supply chain as a whole. As "superior customer value" and "less cost" are relative concepts - relative respectively to some (unstated) "inferior value" and "higher cost", the definition does not provide any theoretical conclusions about when a supply chain is efficient. To the extent, however, that customers signify that the value they receive from one delivery exceeds that of another and that the costs (measured consistently in theory) of the one delivery are lower than those of another delivery, the definition adopted by Lai, et al. (2001) provides an intuitive rather than a theoretical basis for comparing supply chain performance and by implication supply chain efficiency.

The preceding argument explains why it may be fruitless to seek a theory whereby the superior efficiency of structurally-integrated maritime supply chains can be motivated and instead to rely on conclusions derived from the micro-economic analyses of the links in the chains. Such analyses must necessarily concern their cost structures, rather than reported costs, and the extent to which those structures are conducive to the efficient integration of links in the chain in order to avoid disruption of product movement at interfaces, as well as the effect of the structures on pricing policies, including the pricing constraint because of welfare considerations on public enterprises. 


\section{Integrated and autonomous links}

The cost structures of the individual links in maritime supply chains largely determine the scope for improving the overall efficiency of the chains through their integration into single business enterprises. While it can be argued that integrated management does not necessarily imply the integration of cost structures and that each link can function as a separate cost centre under umbrella management, such an organisation virtually precludes scale economies, except perhaps in some overhead expenses. In principle, integrated management enables better co-ordination at interfaces although that depends on the degree of autonomous performance expected by the management of each link. There can be little doubt that a supply chain functioning as one operation for a single purpose is capable of achieving that purpose more efficiently than a supply chain in which the management of each link is striving to perform efficiently even at the expense of other links. The extreme example of an unintegrated supply chain is one in which each link is managed separately as a profit-seeking enterprise irrespective of the costs it may impose on the operation of other links. Another common example of supply chains in which individual links are managed to serve their own purpose at the expense of the overall efficiency of the chain is encountered when some links comprise the operations of monopolistic public undertakings burdened with costs inflated to meet their social obligations.

\section{Purpose of supply chain operation}

The notion that a supply chain can function for a single purpose needs some discussion. That purpose can be the delivery of the product or products it carries to the market at the lowest landed cost, which is the main purpose of supply chain management according to virtually all the literature on the topic, and which serves the business interest of the cargo owner. Such a supply chain would undoubtedly be the Pilbara iron ore supply chain. However, maritime supply chains can also function as entities for the profit of the supply chain operators, although there needs then to be some synergy between the operators and the users, if the product delivered is to survive in the market. Maritime container supply chains providing door-to-door services internationally are enterprises aimed at achieving profits for the liner companies responsible for their operation and are usually priced at what the traffic can bear on routes where shipping conferences or oligopolistic alliances prevail. The marketability or landed costs of the products carried by profit-seeking maritime supply chain operators is a secondary consideration to the purpose of the operators, although it cannot be ignored. This is because the cost structure of liner shipping requires the volume of throughput to be maximised, which is the objective of value-of-service pricing by the liner shipping companies.

It should be noted in this context that although liner companies provide door-to-door container services between South Africa and other countries, undertakings such as ERS do 
not exist locally and reliance is placed on Transnet as a third party service provider for rail and port services. Thus, few, if any, of the supply chains serving South Africa function as entities with links fully integrated to serve the purpose of the chains, but comprise chains of links each oriented towards seeking their own profits (and meeting social obligations) as their foremost purpose.

\section{Efficient structuring of bulk supply chains}

The argument in this article is that the most efficient structure of supply chains carrying exports of ores or minerals is likely to be achieved through the integration of the mining operations with the rail transport and port functions in order to achieve the single purpose of delivering the cargo on board the ships. "Most efficient" in this context means at the lowest unit cost for the entire operation and implies that none of the links in the chain function for the benefit of profit-seeking third party service providers. Efficiency will, of course, also be promoted through the single management of the interfaces between the links. As explained, Transnet (i.e. the Government as sole shareholder) is unlikely to relinquish its ownership of the railways and ports used for the ore and coal supply chains, and outright privatisation of those links for integration with the mining ventures is at present not a prospect for change. In the nature of the technological design of the rail infrastructure and trains as components of integral systems, separation of their operation from the ownership and maintenance of the track would create unnecessary problems and schemes whereby the trains that are privately operated are not acceptable propositions. Another alternative is the nationalisation of the mining operations and the conduct of the export businesses as state enterprises $^{3}$. In fact, the scheme to export iron ore mined at Sishen in the Northern Cape started off as a fully-integrated supply chain including the mine, railway and port, all owned by Iscor (now Mittal Steel South Africa), which was a state enterprise at the time. The remaining option is to amalgamate the mining operations and the transport and port loading links in joint ventures between the mining companies and Transnet, and apportion the returns from export businesses according to the respective shareholdings.

The need to integrate the mining operations with ownership of the land and infrastructure of the transport links in a supply chain may be questioned. However, the aim of achieving the lowest delivered cost of the mined product in international markets is compromised by separating the viability of the transport links from that of the mining operations. The same principle applies if the ownership of the rail and port infrastructure is separated from the operation of the mining enterprises and, for example, a return higher than the economic rent is required on the land and infrastructure. If strategic considerations do not allow state

3 Although provision is made for the nationalisation of industries in the Reconstruction and Development Programme (1994). 
ownership of the port and railway land and infrastructure to be relinquished, it should be possible through long leases at economic rentals to transfer near-ownership to the venture without interposing third party profits.

\section{Efficient structuring of container supply chains}

The concept of supply chains of bulk exports in which the mining of products is integrated with rail links and port handling in order to optimise their efficiency is quite simple and in principle accords with the notion of efficient supply chains contained in academic literature. That integrated container supply chains can also deliver products efficiently to markets, especially when the chains function for the profit of liner companies, needs to be explained. Liner conferences have a long history of freight rate manipulation intended to promote the export of raw materials from developing countries for beneficiation in Europe and the import of the products manufactured in Europe by those countries, in the interests of their trade (Stopford, 1997). Given that value-of-service (or discriminatory) pricing is generally intended to exact "what the traffic can bear", the benefits to importers and exporters when liner companies secure their markets and achieve scale economies by integrating rail services and cargo handling in ports with the marine links, is not evident. In fact, the benefit materialises only when competition in the liner industry forces rates down and obliges competing liner companies to raise the efficiency of their services. This occurs, not necessarily by reducing the costs of delivering the cargo, but by supplying services with the qualities required by their customers - services that enable those customers to reduce inventory costs and adapt quickly to market demand, by being reliable, regular and just-in-time. Those benefits, which reflect the efficiency of container supply chains, can best be produced by liner operators as only the latter can integrate the marine link with the other links. Other third party service providers, including Transnet, would need to enter the liner business to do likewise and function then as liner undertakings operating maritime supply chains.

\section{Supply chain leadership}

Mention has been made of the concept of supply chain leadership and the policy of Government which seemingly does not enable the leadership of maritime supply chain development by mining investors and liner companies (Erwin, 2004). However, public-private partnerships are described in the National Freight Logistics Strategy (South Africa, Department of Transport, 2005: 45) as "a contract between a public sector institution/municipality and a private party, in which the private party assumes financial, technical and operational risk in the design, financing, building and operation of a project. Historically this has been the model used to fund South Africa's toll roads". In the light of that definition, the concept of chain leadership needs further consideration. The Minerals Council of Australia (2005: 29) maintains that "A key feature of best practice global logistics chains is the development of 
a chain leader, with responsibility for driving chain improvements". The motivation for the chain leader to drive improvements should undoubtedly stem from the prospects for gain in countries with economies that are predominantly capitalistic and rely on the free market. If the role of state-owned enterprises in South Africa in accordance with the current policy of the Government does not allow scope for private leadership to drive improvements in the rail and port links of existing and new maritime supply chains and if the leadership of maritime supply chains by mining investors or liner shipping companies is inherent in the structures of efficient chains, the role assigned to Transnet in accordance with Government policy obviously conflicts with best practice global logistics by frustrating private initiative.

The policy of the Government assumes that Transnet will lead the development of rail and port facilities, with private participation if it so chooses, assuming that such participation is forthcoming. As Transnet is required to operate in the market but within rules that are not derived from the logic of the market place alone (Erwin, 2004), considerations of equity as well as efficiency will rule Transnet's leadership. That presupposes an additional purpose for maritime supply chain development, distinguishing Transnet's leadership from that of private investors. The extent to which the competitiveness of South Africa's maritime supply chains in world markets should be forgone by tempering efficiency in the interests of domestic income redistribution is an issue at the root of the country's political economy. Whatever the merits, such a criterion for the development of the rail and port links in maritime supply chains obviously differs from that of best global logistics practice.

\section{MODELS}

In order to compromise between the requirements of world best practice and the policy of the South African Government, structural models (Fourie, 2005) are proposed based on public-private partnerships that should enable competitive efficiency to be improved.

Table 1 shows in separate columns the chains of the main assets and chains of main operations in the Sishen-Saldanha iron ore supply chain (Model 1a) and the Mpumulanga - Richards Bay Coal line (Model 1b). The table also compares the structures of these chains with those of Model 2, which provides for link integration through public-private partnerships, and Model 3 , which would be tantamount to privatisation in the rigorous sense of the term. As indicated, Model 2 provides for the ownership of the supply chain including the mine to the loading of the cargo on board ships, by a public-private partnership, but excludes ownership of the rail and port land and the port infrastructure. The partnership would thus operate the entire chain with Transnet and the National Ports Authority (which is presently a division of Transnet, but may eventually become autonomous) as third party service providers, to the extent that they would let the right-of-way for the railways and the port land and infrastructure to the partnership, and the National Ports Authority would supply marine services in the ports. The public-private partnership could also undertake the ancillary shipping services if deficiencies in the delivery of those services tend to impair the smooth functioning of the chains. 
Table 1: Existing and alternative structures of South Africa's major supply chains for the export of minerals and ores

\begin{tabular}{|c|c|c|c|c|c|c|c|c|}
\hline \multirow[t]{4}{*}{ Link description } & \multicolumn{4}{|c|}{ Existing structures } & \multicolumn{4}{|c|}{ Alternative structures } \\
\hline & \multicolumn{2}{|c|}{ Model 1a } & \multicolumn{2}{|c|}{ Model 1b } & \multicolumn{2}{|c|}{ Model 2} & \multicolumn{2}{|c|}{\begin{tabular}{|l|} 
Model 3 \\
\end{tabular}} \\
\hline & Asset & Operators ${ }^{11}$ & Asset & Operators $^{11}$ & Asset & Operators ${ }^{11}$ & Asset & Operators ${ }^{11}$ \\
\hline & owners & & owners & & owners & & owners & \\
\hline Mines: & & & & & & & & \\
\hline Land & Private firms & Private firms & Private firms & Private firms & $\mathrm{PPP}^{2)}$ & PPP & Private firms & Private firms \\
\hline Loading appliances & Private firms & Private firms & Private firms & Private firms & PPP & PPP & Private firms & Private firms \\
\hline Railway: & & & & & & & & \\
\hline Land & Transnet & Spoornet & Transnet & Spoornet & Transnet & Transnet & Private firms & Private firms \\
\hline Infrastructure & Transnet & Spoornet & Transnet & Spoornet & PPP & PPP & Private firms & Private firms \\
\hline Equipment & Transnet & Spoornet & Transnet & Spoornet & PPP & PPP & Private firms & Private firms \\
\hline Port: & & & & & & & & \\
\hline Land & $N_{P A}^{3)}$ & NPA & NPA & NPA & NPA & NPA & NPA & NPA \\
\hline Terminal & NPA & SAPO ${ }^{4)}$ & Private firms & Private firms & PPP & PPP & Private firms & Private firms \\
\hline Infrastructure & NPA & NPA & NPA & NPA & NPA & $N^{\prime} A^{5)}$ & NPA & Private firms \\
\hline Ships & Shipowner & $\begin{array}{l}\text { Foreign } \\
\text { importer }\end{array}$ & Shipowner & $\begin{array}{l}\text { Foreign } \\
\text { importer }\end{array}$ & Shipowner & $\mathrm{PPP}^{7)}$ & Shipowner & Private firms \\
\hline $\begin{array}{l}\text { Ancillary shipping } \\
\left.\text { services }^{6}\right)\end{array}$ & Private firms & Private firms & Private firms & Private firms & PPP & PPP & Private firms & Private firms \\
\hline \multicolumn{9}{|c|}{ Source: Compiled by the author for the purpose of the study. } \\
\hline & & & & & & \multicolumn{2}{|c|}{ Legend: } & \\
\hline Notes: & & & & & & State enterprise & & \\
\hline \multicolumn{3}{|c|}{ Model 1a: Sishen - Saldanha iron ore chain } & & & & Private enterprise* & & \\
\hline \multicolumn{3}{|c|}{ Model 1b: Mpumulanga - Richards Bay Coal line } & & & & Foreign participant & & \\
\hline \multicolumn{4}{|c|}{ Model 2: Proposed link integration through public-private partnerships } & & & \multicolumn{2}{|c|}{ *Public-private partnerships } & \\
\hline \multicolumn{2}{|c|}{ Model 3: Privatisation (in practice) } & & & & & \multicolumn{2}{|c|}{ are regarded as private enterprise } & \\
\hline \multicolumn{3}{|c|}{ 1) Operators include managers in this table } & & & & & & \\
\hline \multicolumn{9}{|c|}{\begin{tabular}{|l|l|l|l|} 
2) PPP. Public-private partnership & & \\
\end{tabular}} \\
\hline \multicolumn{9}{|c|}{ 3) Presently Transnet, of which the NPA is a division - in terms of Act $12 / 2005$, the NPA will eventually become an autonomous body } \\
\hline \multicolumn{9}{|c|}{\begin{tabular}{l|l|l|} 
4) SAPO: South African Port Operations, division of Transnet & & \\
\end{tabular}} \\
\hline \multicolumn{9}{|c|}{ 5) Marine services (i.e.tug assistance, pilotage, mooring) - could be provided by private undertakings } \\
\hline \multicolumn{9}{|c|}{ 6) Ships agency, chandling, forw arding, documentation, shiprepair } \\
\hline 7) As charterers & & & & & & & & \\
\hline
\end{tabular}

Although the supply of marine services is a task reserved for the National Ports Authority in terms of the National Ports Authority Act, 2005 (Act 12 of 2005), provision is made in the Act for those services (for example, pilotage, tug assistance, mooring and dredging) to be concessioned to private enterprise. Marine services could thus be incorporated eventually in the public-private partnerships envisioned for the ownership and operation of supply chains for bulk exports in order to further their integration, but that could conflict with the declared intention of the Government to involve small to medium black-empowered enterprises in basic port activities. The involvement of those enterprises would create additional profit-seeking third party service providers as links in the chain, whereas the integration of a chain under the leadership of a public-private partnership is intended to eliminate such service providers in the interests of overall chain efficiency.

The structure of Model 3 is not feasible in terms of present Government policy and is shown merely for the purpose of comparison with Model 2, the main difference being the substitution of public-private partnerships for entirely private undertakings. However, public-private partnerships as proposed in the table will function as private enterprises if the chain leadership is entrusted to the investors in the mines in accordance with the motivation in the previous section. 
Table 2: Existing structures and an alternative structure of South Africa's major container supply chains

\begin{tabular}{|c|c|c|c|c|c|c|}
\hline \multirow[t]{4}{*}{ Link description } & \multicolumn{4}{|c|}{ Existing structures } & \multirow{2}{*}{\multicolumn{2}{|c|}{$\begin{array}{c}\text { Alternative structure } \\
\text { Model } 2\end{array}$}} \\
\hline & \multicolumn{2}{|c|}{ Model 1a } & \multicolumn{2}{|c|}{ Model 1b } & & \\
\hline & Asset & Operators ${ }^{1)}$ & Asset & Operators ${ }^{1)}$ & Asset & Operators ${ }^{1)}$ \\
\hline & owners & & owners & & owners & \\
\hline \multicolumn{7}{|l|}{ Consignors: } \\
\hline Suppliers & \multirow{2}{*}{$\begin{array}{l}\text { Private firms } \\
\text { Private firms }\end{array}$} & \multirow{2}{*}{$\begin{array}{l}\text { Private firms } \\
\text { Private firms }\end{array}$} & \multirow{2}{*}{$\begin{array}{l}\text { Private firms } \\
\text { Marketeer }\end{array}$} & \multirow{2}{*}{$\begin{array}{l}\text { Private firms } \\
\text { Marketeer }\end{array}$} & Private firms & Private firms \\
\hline Forwarders & & & & & LSC & LSC \\
\hline Inland terminal: & \multirow{3}{*}{$\begin{array}{l}\text { Transnet } \\
\text { Transnet }\end{array}$} & \multirow{3}{*}{$\begin{array}{l}\text { Transnet } \\
\text { SAPO }^{2}\end{array}$} & n.a. & n.a. & \multirow{3}{*}{$\begin{array}{l}\text { LSC } \\
\text { LSC }\end{array}$} & \multirow{3}{*}{$\begin{array}{l}\text { LSC } \\
\text { LSC }\end{array}$} \\
\hline Land & & & & & & \\
\hline Infrastructure & & & & & & \\
\hline Railway: & \multirow{4}{*}{$\begin{array}{l}\text { Transnet } \\
\text { Transnet } \\
\text { Transnet }\end{array}$} & \multirow{4}{*}{$\begin{array}{l}\text { Transnet } \\
\text { Spoornet } \\
\text { Spoornet }\end{array}$} & n.a. & n.a. & \multirow[b]{2}{*}{ Transnet } & \multirow[b]{2}{*}{ Transnet } \\
\hline Land & & & & & & \\
\hline Infrastructure & & & & & $\mathrm{PPP}^{3)}$ & PPP \\
\hline Equipment & & & & & LSC & LSC \\
\hline $\begin{array}{ll}\text { Road: } & \\
& \text { Infrastructure }\end{array}$ & State & $\begin{array}{l}\text { Government } \\
\text { bodies }^{4)}\end{array}$ & State & $\begin{array}{l}\text { Government } \\
\text { bodies }\end{array}$ & State & $\begin{array}{c}\text { Government } \\
\text { bodies }\end{array}$ \\
\hline Vehicles & Private firms & Private firms & Private firms & Marketeer ${ }^{5)}$ & LSC & LSC \\
\hline Port: & \multirow{4}{*}{$\begin{array}{l}\text { NPA }^{6)} \\
\text { NPA } \\
\text { NPA }\end{array}$} & \multirow{4}{*}{$\begin{array}{c}\text { NPA } \\
\text { SAPO } \\
\text { NPA }\end{array}$} & \multirow{4}{*}{$\begin{array}{l}\text { NPA } \\
\text { NPA } \\
\text { NPA }\end{array}$} & & \multirow{4}{*}{$\begin{array}{l}\text { NPA } \\
\text { NPA } \\
\text { NPA }\end{array}$} & \\
\hline Land & & & & NPA & & NPA \\
\hline Terminal & & & & Marketeer & & LSC \\
\hline Infrastructure & & & & NPA & & NPA $^{7)}$ \\
\hline Ships & LSC & LSC & LSC & Marketeer $^{8)}$ & LSC & LSC \\
\hline & & & & $\operatorname{LSC}^{9)}$ & & \\
\hline $\begin{array}{l}\text { Ancillary shipping } \\
\text { services }^{10)}\end{array}$ & Private firms & Private firms & Private firms & Private firms & LSC & LSC \\
\hline Source: Compiled by the au & thor for the purp & se of the study. & & & & \\
\hline & & & & & & \\
\hline Notes: & & & & & & \\
\hline Model 1a: City Deep - Durbe & an corridor (exan & ple) & & & & \\
\hline Model 1b: Fresh fruit supply & chain & & & & & \\
\hline Model 2: Liner shipping co & mpany (LSC), as & chain leader & & & & \\
\hline 1) Operators include manas & gers in this table & & & & & \\
\hline 2) SAPO: South African Por & it Operations, div & ision of Transnet & & & & \\
\hline 3) PPP: Public-private partn & ership betw een & rans net and LSC & & & & \\
\hline 4) or toll road concessionar & & & & & & \\
\hline 5) Hirer & & & & & & \\
\hline 6) NPA: Presently Transnet & , of which the NF & A is a division - in & terms of Act $12 / 2$ & 5 the NPA will eve & tually become an & utonomous body \\
\hline 7) Marine services (i.e.tug a & ss istance, pilota & e, mooring) - coul & be provided by & vate undertakings & & \\
\hline 8) Charterer of refrigerated & ships & & & & & \\
\hline 9) Cargo shipped on liners & & & & & & \\
\hline 10) Ships agency, chandling & g, forw arding, do & cumentation, shipr & pair & & & \\
\hline & & & & & & \\
\hline Legend: & & & & & & \\
\hline State enterprise & & & & & & \\
\hline Pivate enterprise* & & & & & & \\
\hline Foreign LSC & & & & & & \\
\hline *Includes PPPs and other pr & rivate enterprises & & & & & \\
\hline
\end{tabular}

The existing structures and proposed alternative to the main container supply chains in South Africa are illustrated in Table 2. In accordance with the intentions of the Government set out in the National Freight Logistics Strategy (2005), state ownership of the land used for ports, 
railways and roads and the port infrastructure and terminals, is retained in all the models, but provision is made for rail infrastructure to be owned by a public-private partnership. That would apply to the railway between Coega and Gauteng ${ }^{4}$, which needs to be upgraded if the proposed new container terminal in the port of Ngqura is to serve Gauteng, as a likely public-private participation project. Model 2 shows the structure of a container supply chain integrated under the leadership of a liner shipping company, which would have control over the entire chain, subject to third party intervention only by rail and port landlords. It needs to be noted, however, that while rentals for land can be determined at market prices and thus not affect the cost-efficiency of the chain, the charges for the use of the basic port infrastructure can do so 5 . Thus port and cargo dues imposed by the National Ports Authority and currently used to subsidise the other enterprises of Transnet are tantamount to external costs that affect the international competitiveness of maritime supply chains.

The private rail operations would need to carry some traffic for third parties in order that rail capacity on scheduled trains could then be sold at spot prices when ships are delayed and intermodal co-ordination is disrupted. The arrangement implies that the operator of container chains would offer limited (i.e. limited to spot use) common user services in competition with Spoornet, and could do so at marginal cost, which is conceptually obviously a cause of concern for Transnet. ${ }^{6}$

There can be no doubt that the landside integration of container supply chains at the South African end of international routes will have to come about if South African manufacturers are to raise or at least retain their ability to compete with foreign manufacturers. The benefits for South Africa of reliable just-in-time scheduled container services in contrast to the present system of distribution, which often involves uncertain delivery times and requires the tracking of containers to ascertain the progress of the movement, are indisputable.

\section{CONCLUSIONS}

The general argument in this paper is that the structures of South Africa's maritime supply chains, which incorporate links provided by State and private enterprises without overall decision-making leadership, do not enable their vertical integration to match the efficient structures of rival chains in international markets. Rail and port links are currently

4 The Port of Ngqura at Coega (near Port Elizabeth) is a new port which will be equipped with a container terminal. As yet the function of the port in South Africa's port system is undefined.

5 The charges for the use of port infrastructure (port and cargo dues) are arbitrarily determined at present and far exceed the opportunity costs of that use.

6 This came out when the concessioning of the container terminal in the port of Ngqura was discussed between P\&O Nedlloyd and Spoornet. 
underperforming because investment in capacity has been neglected during the past two decades and the morale of the personnel is low (South Africa, Department of Transport, 2005). Although Transnet has promised substantial new investment in infrastructure and equipment (i.e. R40bn) (Ramos, 2005) over the next five or more years, it does not necessarily guarantee the development of efficient and seamless (i.e. seamless at interfaces) supply chains for imports and exports, nor does it ensure that their capacity and performance will henceforth match the demand. Indeed, Transnet's management has acknowledged that the investment is intended to rectify existing problems rather than provide for traffic growth. Furthermore, no promises have been made in the announcements concerning new investment for that to be accompanied by chain leadership that will advance the restructuring of the links in maritime supply chains to ensure the seamless flow of cargo under single management.

The solutions to the current problems with South African maritime supply chain performance proposed in this article differ from resorting to privatisation, as such. Users of the bulk export chains will not be third parties dependent on Transnet's investment acumen and operational performance, but investors responsible for such investment and performance themselves and the bearers of the risks. While the users of the container supply chains will remain third parties, the essential feature of the proposals is the creation of competition between the services of liner shipping companies managing and operating entire supply chains from door-to-door and the services of container operators relying on the capacities and performances of the common-user facilities provided by divisions of Transnet. In that manner the rigour of the market will permeate the service delivery of Transnet and eliminate the inefficiencies of its current monopoly of container handling in the ports. State participation in the investment in entire bulk supply chains should ensure that the resources are not exploited regardless of the environmental consequences and the opportunities for beneficiation, and will result in a return on the investment that can be applied in the interests of the welfare of the population, preferably in the vicinity of the mining operations and supply chain routes. State participation in the container supply chains will be limited to investment in the partnership responsible for the provision of rail infrastructure and the land on which the railways and port container terminals are situated. That, together with competition between supply chain services, will be sufficient to preclude private monopolies evolving through mergers or alliances, although the Competition Commission will need to be alert to the local effects of international trends in the container shipping industry, which are moving towards a concentration of ownership. 


\section{REFERENCES}

Australia. Minerals Council of Australia. 2005. Submission to the Prime Minister's infrastructure taskforce. Kingston ACT: Government Printing Office: 29.

Christopher, M. 1998: Logistics and supply chain management. London: Pitman Publishing, (Second edition): 294.

Erwin, A. 2004. Public enterprises budget vote. National Assembly, Pretoria, June 2004.

European Rail Shuttle (The Netherlands) (Online). 2005. ERS - The strategic rail-link within Europe. Available: . (July 2005).

Fourie, Y. 2002. Integrated intermodal supply chains in South Africa. Unpublished master's dissertation, Stellenbosch: University of Stellenbosch.

Fourie, Y. 2005. Structuring South Africa's maritime supply chains for higher efficiency. Unpublished doctoral thesis, Johannesburg: University of Johannesburg.

Hamersley Iron (Online). 2005. Pilbara iron. Available: http://www.hamersleyiron. (July 2005).

Kumba Resources. 2002. Sishen iron ore. Cape Town: Dyason Design \& Print: 12.

Lai, K., Ngai, E.W.T. \& Cheng, T.C.E. 2001. Measuring supply chain performance in transport and logistics related industry. Paper presented at IAME 2001 annual conference, 18-20 July, Hong Kong.

Langley Jr, C.J. 1995. Logistics, the strategic issues. London: Chapman \& Hall (Reprinted).

Merit (Pty) Ltd. 2000: South Africa's maritime industries. Stellenbosch: Unit for Maritime Studies: 50.

Ramos, M. 2005. Transnet strategy and infrastructure plan. Paper presented at the $9^{\text {th }}$ National Maritime Conference, 15-17 March, Cape Town, South Africa.

Republic of South Africa. 1989. Legal Succession to the South African Transport Services Act, Act 9 of 1989. Pretoria: Government Printer.

Republic of South Africa. 1994. Reconstruction and Development Programme White Paper (Government Gazette 16085, Notice 1954). 23 November 1994. Pretoria: Government Printer. 
Republic of South Africa. 2005. National Ports Authority Act, Act 12 of 2005. Pretoria: Government Printer.

Republic of South Africa. 2005. Department of Transport: National freight logistics strategy: 61.

Spoornet (Online). 2005. Available: http://www.spoornet.co.za (6 June 2005).

Stopford, M. 1997. Maritime economics. London: Routledge, (Second edition): 562. 